\title{
MANAGEMENT OF BACTERIAL WILT (Ralstonia solanacearum) OF POTATO: FOCUS ON NATURAL BIOACTIVE COMPOUNDS
}

\author{
Karim, Z. and M. S. Hossain ${ }^{1}$ \\ Senior Scientific Officer, Plant Pathology Division, Bangladesh Agricultural Research Institute (BARI), \\ Joydebpur, Gazipur 1701, Bangladesh; ${ }^{1}$ Department of Entomology, Sher-E-Bangla Agricultural \\ University, Agargaon, Dhaka, Bangladesh
}

\begin{abstract}
The bacterial wilt disease caused by Ralstonia solanacearum is an extremely destructive soil borne bacterial pathogen to potato. It appeared as rapid and fatal wilting symptoms in the host. The pathogen entered through different wounds and easily disseminated via infected biological material, soil, contaminated irrigation water, surface water, farm equipment etc. and could survive for many years in association with alternate hosts. It is a widely distributed and very much diversified soil borne pathogen having an unusually broad host range with long-term survivable ability. Direct yield losses caused by the pathogen varied from 30 to $90 \%$ depending on different factors such as cultivar, weather factors, soil type, cropping pattern and strain etc. Bacterial wilt continued to be an economically serious problem for field-grown potatoes in many tropical, subtropical and warmer areas of the world including Bangladesh. But the effectiveness of conventional management is limited because of some special biological features of the bacteria. Mostly protective methods and chemical control remain ineffective, antibiotics show hardly any effect, and efficacious biocontrol method has yet to be developed against the organism. However, during the recent decades, some natural bioactive compounds, viz. propolis, honey, turmeric, magnesium chloride, cow dung, aromatic rice extract, iodine, sodium bicarbonate etc. have got attention for their effectiveness in inhibiting a range of serious bacterial pathogens from both Gram positive and Gram negative types. As no conventional method has been found effective alone, such compounds could be tested for their effectiveness against the very successful soil borne bacteria to overcome the traditional management limitations.
\end{abstract}

Key words: Management, Ralstonia solanacearum, potato, natural bioactive compounds.

\section{INTRODUCTION}

Potato (Solanum tuberosum L.) is cultivated and recognized as a popular vegetable throughout the tropical and subtropical regions (Hayward 1991a). Potato is best known for its carbohydrate content (approximately 26 grams in a medium potato) and it is a high energy food that contains about $80 \mathrm{kcal}$ per 100 grams of fresh product. The potato has vital role to human nutrition (Horton 1987). It produces more carbohydrates than either rice or wheat. It has great economic significance. Its production provides jobs and food security to some 800 million people globally (Hoffler and Ochieng 2008). Bangladesh is the $7^{\text {th }}$ producer country in the world by producing 86.03 lakh tons of potato. However, the yield of potato is comparatively lower in the country to the major potato growing countries like- Ireland and India. Lower soil fertility, inadequate supply of certified seeds, use of low yielding varieties, different pests and diseases etc. are the reasons behind the lower yield. Among those, soil borne diseases are considered to cause a yield loss of as much as 10-20\% annually (USDA 2003).

Ralstonia solanacearum (Smith, 1896) is the most destructive soil-borne pathogen (Yuliar et al. 2015) that affects potatoes in temperate, subtropical and tropical regions by causing bacterial wilt or brown rot disease (Champoiseau et al. 2009). The Gram negative bacterium normally invades plant roots from the soil through wounds or natural openings, colonizes the intercellular space of the root cortex and vascular parenchyma, and eventually enters the xylem vessel and spreads into the stem and leaves (Yuliar et al. 2015). Infected potato plants die rapidly within 3-4 days and disease severity mostly increases when it is found associated with root nematodes (Sitaramaiah and Sinha 1984). The tuber carries the pathogen in vascular tissues, on tuber surface and within lenticels as tolerant or latent carrier 
(Ghosh and Mandal 2009). Yield losses due to the disease varied from 33 to $90 \%$ in the potato growing areas of the world (Elphinstone 2005). Direct yield losses caused by R. solanacearum depending on the host, cultivar, climate, soil type, cropping pattern and strain. The total value of Egyptian potato exports fell from a peak of US\$ 102.12 million in 1995 to US\$ 7.7 million in 2000 mainly due to brown rot quarantine, imposed by the European Union (EU) (Kabeil et al. 2008). In India, this disease causes 50\% crop loss in a regular manner (Mukherjee and Dasgupta 1989) and up to 75\% losses are reported in some areas of Karnataka (Gadewar et al. 1991). In Bangladesh more than $30 \%$ of potato crops affected by $R$. solanacearum, with over 14\% reduction in yield (Elphinstone 2005).

Geographic distributions of the pathogen are highly influenced by the factors like availability and abundance of the host(s), and suitability of the climatic conditions etc. Its world-wide distribution and destructive nature over 450 plant species resulted it to be the most important bacterial plant pathogen (Kelman 1998, Prior et al. 1998). The bacterial wilt pathogen is very diversified, widely distributed and has an extensively wide host range (over 200 species) with major host crops like potato, tomato, Musa spp. etc. and some minors like groundnuts (Arachis hypogaea), brinjal (Solanum melongena) and ginger (Zingiber officinalis) (Denny 2006, Hayward 1991a). Moreover, the bacterium is known to enter in VBNC state (viable but not culturable) under unfavorable conditions (van Elsas et al. 2001). Such biological phenomena of the pathogen help it to build up the inoculum potential which lead it to induce a destructive economic impact (Kelman 1998). $R$. solanacearum is a very successful plant pathogen. Due to the speciality in biological features of it, several difficulties are created in effective management through traditional practices which include: i) controlling the pathogen through preventive options is not applicable to infested location; ii) cultural options show limited success because the pathogen is able to survive in a very wide host range along with asymptomatic weed hosts and in soil for a long period of time ((Mbaka et al. 2013, Saddler 2005); iii) the complexities due to pathogen strain(s), host and environmental interactions make the resistant breeding extremely difficult (Tung et al. 1990); iv) using antibiotics against the pathogen is a challenge. Because the bacteria localize inside the xylem, and antibiotics (viz. streptomycin, ampicillin, tetracycline and penicillin) could show hardly any effect; in fact, streptomycin increases the incidence in Egypt (Farag et al. 1982); v) soil fumigants show either slight or no effect except chloropicrin among other fumigants like methyl bromide, DD MENCS (a mixture of methyl isothiocyanate, dichloropropane and dichloropropene), and metham (Enfinger et al. 1979); but it was used as tear gas and "vomiting gas" during 'World War I' and scientists warned about chronic exposure of chloropicrin which might result in "very high" cancer risks (Froines 2010); vi) biological control has been investigated with some positive reports with Bacillus amyloliquefaciens, Ralstonia pickettii and Pseudomonas mallei but efficacious biocontrol agents with easier application method and survivability of the agent(s) remain as a major barrier for large scale application in the field(Yuliar et al. 2015).

During the recent decades, many natural bioactive compounds have been extensively tested and a good number of reports have documented the antimicrobial effects of such compounds as effective inhibitors of dangerous strains of phytopathogenic bacteria (Leksomboon et al. 2000). A wide range of pharmacological attributes of curcumin from turmeric has been well documented for antimicrobial and protective properties (Nagabhushan and Bhide 1992). Cow dung and urine have been used as insecticides and reported that they contained antibiotic agents (Waziri and Suleiman, 2013). Oyarzua et al. (2014) showed that the magnesium salts in the microbiological experiments are associated with positive effects. It focuses on the usefulness of magnesium (in form of $\mathrm{MgCl}_{2}$ ) as a stress enhancer against Escherichia coli. The reduction of wilt has been noted by Chellemi et al. (1992) with natural and organic amendments. Two traditional aromatic rice genotypes, viz. Kalijira and Chinigura, effectively inhibit the Gram negative type Agrobacterium tumefaciens (Mannan et al. 2014). Iodine (mixed with a transporter known as iodofore) can inhibit aerobic Gram positive and Gram negative 
bacteria (Estrela et al. 2006). Sodium bicarbonate has shown antibacterial properties against different types of bacterial and fungal pathogens (Kelly and Kristin 2005, Malik and Goyal 2006, Arslan et al. 2009). However, a review work has been performed to investigate the success of such antibacterial properties of different natural bioactive compounds against severe starin(s) of bacterial pathogen as alternative approach of management. Therefore, the present study emphasizes the review of effectiveness and inhibition capabilities of such bioactive compounds as antibacterial agents which may be considered during the management of $R$. solanacearum in potato crops.

\section{Detection}

\section{MATERIAL AND METHODS}

The bacteria $R$. solanacearum is considered to be a "species complex" due to significant variation within the group (Fegan and Prior 2005). It identified from either symptomatic or asymptomatic plants and from water or soil samples by means of several microbiological and molecular methods (Weller et al. 2000). Screening tests can facilitate early detection of $R$. solanacearum in plants or contaminated soil and water samples, but they cannot be used to identify the race or biovar. These screening tests include bacterial streaming, plating on a semi-selective medium, such as TZC medium etc., polymerase chain reaction (PCR) with specific primers, and pathogenicity tests using susceptible hosts, such as tomato seedlings (Elphinstone et al. 1996, Weller et al., 2000). Commercially available immunostrips can be used for the rapid detection of $R$. solanacearum in the field or lab. Isolation from symptomatic material can easily be performed using Kelman's tetrazolium chloride (TZC) medium. In case of secondary infections, the isolation of the pathogen on selective media was necessary. Biovar test is a biochemical assay which can be identified from a panel of disaccharides and sugar alcohols (Hayward (1994b). It was based on their ability to utilize three hexose alcohols (mannitol, sorbitol and dulcitol) and to produce acids from the three disaccharides, lactose, maltose and cellobiose (Table 1).

Table 1. Identification of biovars of $\boldsymbol{R}$. solanacearum based on the utilization of certain carbohydrates (Hayward 1994).

\begin{tabular}{ccccccc}
\hline \multicolumn{2}{c}{ Charbohydrate } & Biovar 1 & Biovar 2 & Biovar 3 & Biovar 4 & Biovar 5 \\
\hline \multirow{3}{*}{ Hexose alcohol } & Mannitol & - & - & + & + & + \\
& Sorbitol & - & - & + & + & - \\
& Dulcitol & - & - & + & + & - \\
\hline \multirow{3}{*}{ Disaccharides } & Lactose & - & + & + & - & + \\
& Maltose & - & + & + & - & + \\
& Cellobiose & - & + & + & - & + \\
\hline \multicolumn{5}{c}{ ' } & indicates utilization of hexose alcohol and acid production &
\end{tabular}

This test requires specialized media and it may take several days to several weeks. The strains of $R$. solanacearum can be sub-classified into phylotypes and then into sequevars using PCR and gene sequence analysis (Champoiseau et al. 2009). Many standard methods for the detection (of latent infection), identification and preparation of media for $R$. solanacearum, used in official EU testing schemes. Detection of latent infection is performed by an immuno-fluorescence test and/or selective plating on SMSA medium eventually combined with optional PCR assays, ELISA or fluorescent in situ hybridization tests which can be performed for added sensitivity. A combination of at least two different complementary tests is required to identify the species and biovar unambiguously. Unequivocal identification of R3bv2 must rely on at least two distinct methods of screening and biovar test (Champoiseau et al. 2009). SMSA medium as modified by Elphinstone et al. (1996) has been used successfully in Europe for latent infection (Elphinstone et al. 1998). A presumptive test in the field can be the water streaming test as described under disease symptoms or a serological agglutination test using a field kit in the form of a lateral flow device (Danks and Barker 2000). 


\section{Colony character}

On solid agar media, individual bacterial colonies are usually visible after 36 to 48 hours growth at $28^{\circ} \mathrm{C}$. the colonies of the normal or virulent type are white or cream-colored, irregularly shaped, highly fluidal, and opaque. A tetrazolium chloride (TZC) medium (Kelman 1954) can differentiate the virulent and non-virulent colony types by appearing as white with pink centers (Fig. 1) of virulent colonies and dry, uniform round and dark red of non-virulent/ mutant colonies. However, it has the ability of changing state from virulent to avirulent, termed as "phenotypic conversion" (PC) by reduced production of extracellular proteins and polysaccharides due to some environmental stress (Shekhawat and Perombelon 1991).

\section{RESULTS AND DISCUSSION}

\section{Symptom of Bacterial Wilt Disease (Ralstonia solanacearum) in Potato}

A plant showing wilting can be suspected to have $R$. solanacearum infection. The symptom starts with slight wilting (Fig. 1a and b.) of the leaves at the ends of the branches during the day which recovers at night; eventually, plants fail to recover which is soon followed by total wilting. Milky or cloudy threads like streaming signifies the presence of $R$. solanacearum of bacterial wilt disease (Fig. 1a) while the cut end of infected stem kept in a glass of water. Streaming is clearly observed when the bacterial population in the vascular bundles is high, due to the blocking of the vessels specifically in the xylem (Kelman 1953); low populations of the pathogen may not be visible to the naked eye. Infected symptomatic tuber shows browning of vascular bundle region (Fig. 1c.).

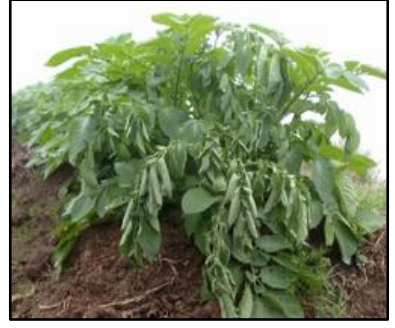

a

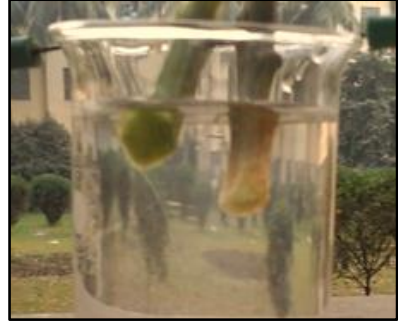

b

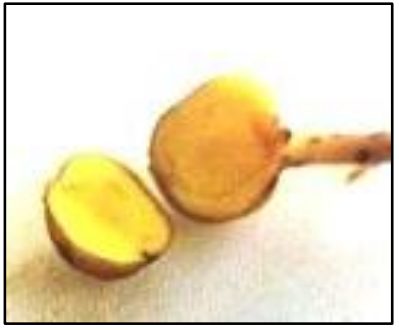

C

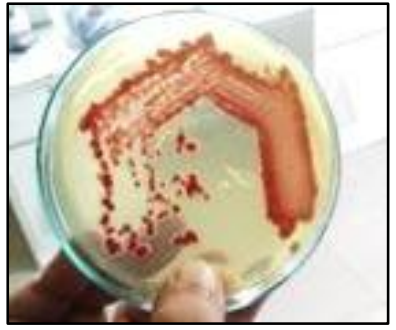

$\mathrm{D}$

Fig. 1. Bacterial wilt infected potato stem: a) early symptom, b) cloudy thread like bacterial streaming; brown rot infected potato tubers: c) vascular browning symptom, (d) colonies of $R$. solanacearum on Kelman's TZC medium.

\section{Diversity of the Pathogen}

Ralstonia solanacearum is a heterogeneous species complex comprising of four broad genetic groups. The existence of these four groups was confirmed by Guidot et al. (2007). Cook et al. (1989), and Cook and Sequeira (1994) divided the species $R$. solanacearum into 46 multilocus genotypes (MLGs) based upon restriction fragment length polymorphism (RFLP) analysis. Several attempts have been made to find a suitable classification system (Table 2). It was historically subdivided into five races based loosely on host range, five biovars, and a phylogenetically meaningful system based on DNA sequence analysis (Fegan and Prior 2005). They classified $R$. solanacearum into four major genetic groups called phylotypes (Table 2). Within each of the races or biovars there are numerous subtypes that can be associated with certain geographical regions (He 1983). Therefore, it affects crops of economic importance in almost all the tropical, subtropical and warmer temperate regions of the world. Biovar 2 presumed to have originated in South America and has a wide spread distribution in many countries of Southern Europe, the Mediterranean area, Argentina, Chile and Uruguay (Hayward 1991a). Biovars 1 and 2 are predominant in the Americas, Biovar 3 predominates in Australia, and Biovars 2, 3 and 4 occurs in India, Indonesia, Papua New Guinea, Sri Lanka and China (together with Biovar 5). 
Only Philippines have all of biovars 1-4, and biovar 3 predominates in the lowland regions in Asia and Bangladesh (Ahmed et al. 2013).

Table 2. Diversity eequivalences among phylotypes, biovars and races of $R$. solanacearum (Fegan and Prior 2005).

\begin{tabular}{|c|c|c|c|c|c|c|c|c|c|c|c|c|c|}
\hline Group & \multicolumn{13}{|c|}{ Diversity eequivalences } \\
\hline Phylotype & \multicolumn{3}{|c|}{$\mathrm{I}$} & \multicolumn{3}{|c|}{ II } & \multicolumn{2}{|c|}{ III } & \multicolumn{5}{|c|}{ IV } \\
\hline Biovars & 3 & 4 & 5 & $2 \mathrm{~T}$ & 1 & 2 & $2 \mathrm{~T}$ & 1 & $2 \mathrm{~T}$ & 1 & 2 & $\mathrm{R}$ & $\mathrm{B}$ \\
\hline Races & 1 & 4 & 5 & 1 & 2 & 3 & & & & & & & \\
\hline
\end{tabular}

\section{Economic Impact of $R$. solanacearum}

$R$. solanacearum is the most serious pathogen of solanaceous plants in tropics and subtrops. It can cause serious losses even in temperate regions (Elphinestone 2005, Ajanga 1993, Coelho and Nutter 2005). The disease affects about 1.7 million hectares of potatoes in 80 countries (Champoiseau et al. 2009, Floyd 2008). It is responsible for an estimated $\$ 1$ billion in losses each year (Elphinstone 2005). In Bangladesh, the loss caused by $R$. solanacearum was recorded in Munshigonj (22.65\%) as compared to Nilphamari (19.98\%) and Jamalpur area (9.07\%) (Ahmed et al. 2013).

\section{Biological strategy of long-term survivability of $R$. solanacearum}

The bacterial wilt pathogen has an unusually broad host range because of being a soil-borne pathogen and host resistance is limited (Denny 2006, Hayward 1991, Saddler 2005). R. solanacearum possesses some especial biological features (Table 3). These are i) the pathogen possesses, extensively wide (over 200 species) and worldwide distributed major host crops like groundnuts (Arachis hypogaea), Capsicum annuum, cotton (Gossypium hirsutum), rubber (Hevea brasiliensis), cassava (Manihot esculenta), castor beans (Ricinus communis), brinjal (Solanum melongena) and ginger (Zingiber officinalis) with many weeds as asymptomatic alternate hosts to induce a destructive economic impact (Kelman 1998); ii) disease severity mostly increases if $R$. solanacearum is found in association with root nematodes.

Table 3. Biological features behind management constraints.

\begin{tabular}{|c|c|c|}
\hline $\begin{array}{l}\text { Biological } \\
\text { feature }\end{array}$ & Factor & Condition \\
\hline Mode of entry & $\begin{array}{l}\text { i) Wound created by } \\
\text { nematodes or other } \\
\text { ii) Unwounded root } \\
\text { infection is also possible }\end{array}$ & $\begin{array}{l}\text { Especially the root-knot nematode (Meloidogyne spp.) (Johnson and Schaal } \\
\text { 1952, Kelman, 1953); the bacterium could enter the host through points of } \\
\text { secondary root emergence (Kelman 1953, Buddenhagen and Kelman 1964, } \\
\text { Kelman and Sequeira 1965) } \\
\text { When relatively large numbers of bacteria are available (Kelman and Sequeira } \\
\text { 1965). }\end{array}$ \\
\hline
\end{tabular}




\begin{tabular}{|c|c|c|}
\hline & $\begin{array}{l}\text { Soil moisture } \\
\text { irrigation }\end{array}$ & $\begin{array}{l}\text { (Granada and Sequeira 1983b). } \\
\text { Bacteria could be disseminated with the irrigation water in the environment } \\
\text { and could make the disease level increased and affected synergically while in } \\
\text { the optimum temperature (Shekhawat et al. 1992). }\end{array}$ \\
\hline Survival & "PC" phenomena & $\begin{array}{l}\text { As a soil-borne pathogen, it can survive in various types of soils worldwide. It } \\
\text { has the ability of changing state [from virulent to avirulent termed as } \\
\text { "phenotypic conversion" (PC) by reduced production of extracellular proteins } \\
\& \text { polysaccharides]. It makes them to remain withstand \& viable for a very } \\
\text { long periods like } 2 \text { to } 10 \text { years (Denny et al. 1994, Poussier et al. 2003, } \\
\text { Nesmith and Jenkins 1985). }\end{array}$ \\
\hline Latency & $\begin{array}{l}\text { Inoculum level decrease } \\
\text { and certain environmental } \\
\text { stresses. }\end{array}$ & $\begin{array}{l}\text { Exists when inoculum level decrease and certain environmental stresses } \\
\text { occurs. Such as exposure to low temperatures, dryness etc. makes them } \\
\text { symptomless \& undetectable [termed as- viable but non culturable (VBNC) } \\
\text { state] (Devi et al. 1982, Shekhawat and Perombelon 1991). "VBNC" observed } \\
\text { as- "not all tubers get infected in the symptomatic plants rather diseased tubers } \\
\text { occasionally found on the asymptomatic plants" (Eddins 1941). }\end{array}$ \\
\hline
\end{tabular}

Disease severity mostly increases by changing the physiology of the plants and increases the susceptibility if $R$. solanacearum is found in association with root nematodes (Chen 1984). It cannot be detected in seeds with a water content of less than 10\% (Zhang et al., 1993). Therefore, seed-borne latent infection may result in severe out-breaks of bacterial wilt and/or brown rot of potato.

\section{Limitation of traditional management practices}

The survival strategies of the pathogen successfully created difficulties and limited the management success through traditional management practices viz. i) preventive measures, ii) cultural measures, iii) chemical measures, and iv) biological measures (Table 4).

Table 4a. Success and limitations of different management practices against bacterial wilt pathogen.

\begin{tabular}{|c|c|c|c|}
\hline \multicolumn{2}{|r|}{ Types of Management } & Success & Limitation \\
\hline 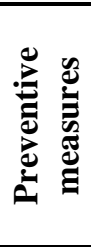 & $\begin{array}{l}\text { Quarantine, } \\
\text { practices, disease free certified } \\
\text { seeds, disinfected equipment, } \\
\text { controlled use of flood } \\
\text { irrigation and avoiding overhead } \\
\text { irrigation etc. }\end{array}$ & $\begin{array}{l}\text { It is successful where the } \\
\text { pathogen is not present. }\end{array}$ & Not applicable in infested location. \\
\hline 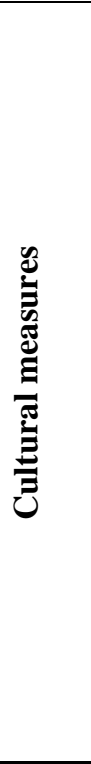 & i. Use of resistant cultivars & $\begin{array}{l}\text { It is reported to be the } \\
\text { most effective and } \\
\text { practical method to } \\
\text { control bacterial wilt } \\
\text { (Black et al. 2003, } \\
\text { Grimault et al. 1994). }\end{array}$ & $\begin{array}{l}\text { Because- i. the pathogen is able to survive } \\
\text { in the soil over a long time; ii. it can exist } \\
\text { in a very wide range of weeds and } \\
\text { volunteer crops (Fajinmi and Fajinmi } \\
\text { 2010). } \\
\text { Unfortunately the complexities of host- } \\
\text { pathogen-environment interaction make } \\
\text { breeding for resistance extremely difficult } \\
\text { (Tung et al. 1990). Because- i. R. } \\
\text { solanacearum is a "heterogeneous species } \\
\text { complex" with a wide host range (Kelman } \\
\text { and Person 1961); ii. high variability in its } \\
\text { biochemical properties (Cuppels et al. } \\
\text { 1978, Hayward 1964), serological reactions } \\
\text { (Schaad et al. 1978), membrane proteins } \\
\text { (Dristig and Dianese 1990) and phase } \\
\text { susceptibility (Okabe and Goto 1963) } \\
\text { confirming the challenges in breeding for } \\
\text { resistance. }\end{array}$ \\
\hline
\end{tabular}




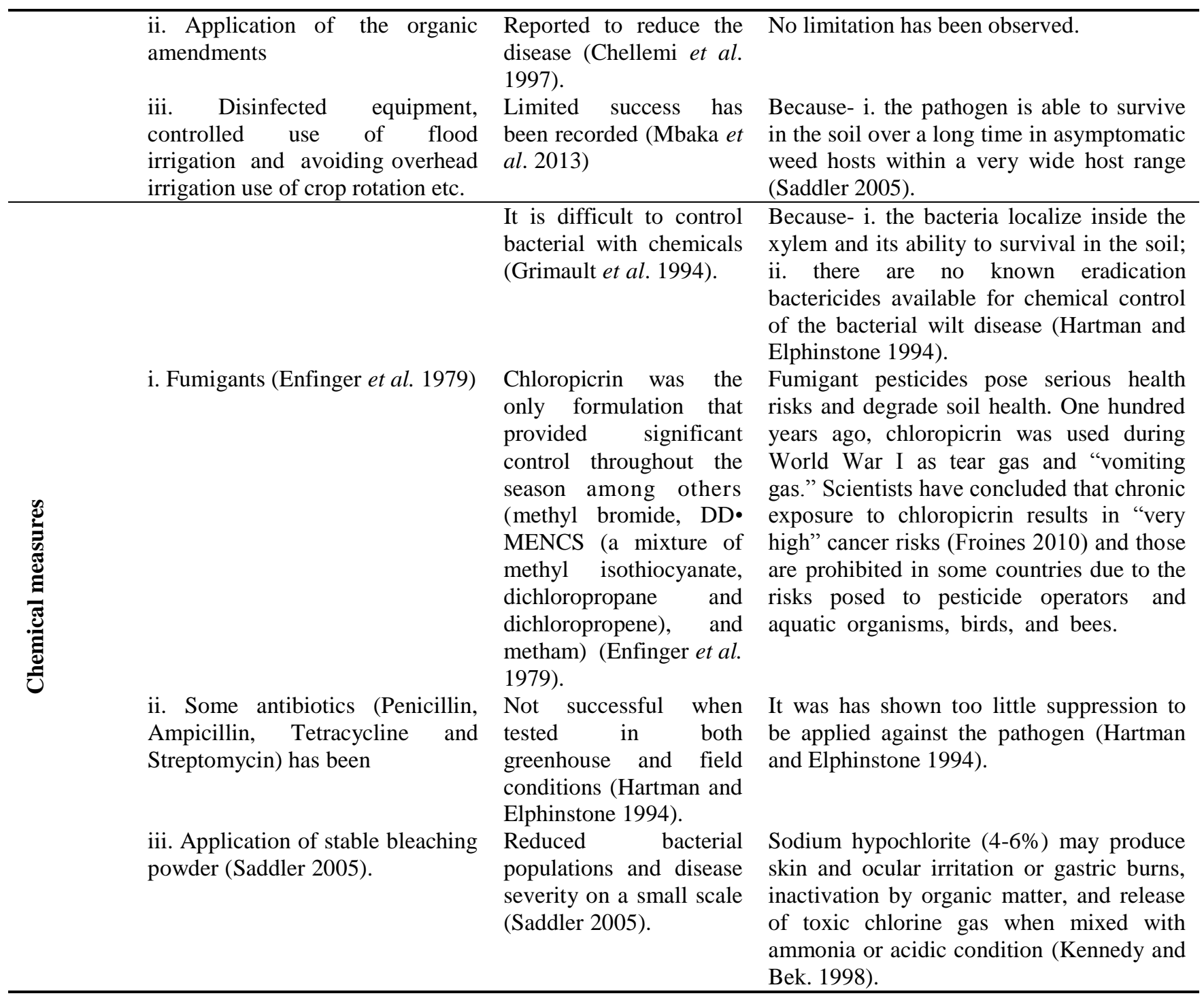

Cultural options has been limited success because the pathogen is able to survive in the soil over a long time with asymptomatic weed hosts and a very wide host range ((Mbaka et al. 2013, Saddler 2005). The complexities of host-pathogen-environment interaction make breeding for resistance extremely difficult (Tung et al. 1990). There are no known eradication bactericides available for chemical control of the bacterial wilt disease (Hartman and Elphinstone 1994). Antibiotics, streptomycin, ampicillin, tetracycline and penicillin showed hardly any effect (Farag et al. 1982).

Biological control has been investigated and gained popularity in recent years. But efficacious biocontrol agents have yet to be developed. Positive results were achieved with the antagonistic bacteria Bacillus amyloliquefaciens, Ralstonia pickettii, Pseudomonas mallei (Yuliar et al. 2015). However, different problems (formulation of user friendly application and poor performance due to inconsistent colonization in the field) have been reported challenging to use on a commercial scale (Akira et al. 2009).

\section{Environment friendly management options to be considered against bacterial wilt disease of potato}

During the recent decades, many natural bioactive compounds have been extensively tested and a good number of reports outlined the antimicrobial effects of those compounds for dangerous pathogenic 
strains and documented as effective inhibitors of phytopathogenic bacteria (Leksomboon et al. 2000). Turmeric (Curcuma longa L.) is a medicinal plant. It is used as a food additive (spice), preservative and colouring agent in Asian countries, including China and South East Asia (Khattak et al. 2005). It is effective against different virulent strains of $R$. solanacearum in India (Narasimha et al. 2015). The chemical composition, medicinal and antibacterial activity of propolis from bees has been reported by Velikova et al. (2000 a,b). Honey contains antioxidants and flavonoids that might function as antibacterial agents. Propolis, a flavonoid-rich product of honey comb, exhibited antibacterial properties (Bosio et al. 2000) against both Gram negative and positive type bacteria. Honey inhibited the growth of dangerous bacteria from both Gram negative and positive type such as Escherichia coli, Staphylococcus aureus, Salmonella etc. (Zumla and Lulat 1989).

Table 4b. Success of biological management practices against the bacterial wilt during 2005-2014 (Yuliar et al. 2015).

\begin{tabular}{|c|c|c|c|}
\hline Microorganisms & **Inoculation method and application rate & Mechanisms & $\begin{array}{c}\text { Success in yield } \\
\text { increase }\end{array}$ \\
\hline $\begin{array}{l}\text { Bacillus amyloliquefaciens } \\
\text { SQR-7 and SQR-101 and } \\
\text { B. methylotrophicusn } \\
\text { SQR-29 }\end{array}$ & $\begin{array}{c}\text { Pouring, } 6.8 \times 10^{10} \mathrm{cfu} \mathrm{clant}^{-1}(\mathrm{SQR}-7) \\
7.5 \times 10^{10} \mathrm{cfu} \mathrm{plant}^{-1}(\mathrm{SQR}-101) \\
8.2 \times 10^{10} \mathrm{cfu} \mathrm{plant}^{-1}(\mathrm{SQR}-7)\end{array}$ & $\begin{array}{l}\text { Production of indole } \\
\text { acetic acid and } \\
\text { siderophores }\end{array}$ & $25-38 \%$ \\
\hline Ralstonia pickettii QL-A6 & Stem injection, $10 \mu \mathrm{L}$ of $10^{7} \mathrm{CFU} \mathrm{mL}^{-1}$ & Competition & Not Applicable \\
\hline $\begin{array}{l}\text { Pseudomonas monteilii (A) } \\
+ \text { Glomus fasciculatum (B) }\end{array}$ & $\begin{array}{c}\text { Stem cuttings were dipped in } \mathrm{A}\left(9.1 \times 10^{8} \mathrm{~mL}^{-1}\right) \\
\text { B (53 infective propagules) was added to each } \\
\text { cutting, and A was then poured again }\end{array}$ & $\begin{array}{l}\text { Increased plant nutrient } \\
\text { uptake }(\mathrm{N}, \mathrm{P}, \mathrm{K}) \text { and reduced } \\
\text { the pathogen population }\end{array}$ & $54 \%$ \\
\hline $\begin{array}{l}\text { Brevibacillus brevis } \mathrm{L}-25+ \\
\text { Streptomyces roche } \mathrm{L}-9+ \\
\text { organic fertilizer }\end{array}$ & $\begin{array}{l}\text { Mixed with soil at a density of } 7.3 \times 10^{7}(\mathrm{~L}-25) \\
\text { and } 5.0 \times 10^{5}(\mathrm{~L}-9) \mathrm{cfu} \mathrm{g}^{-1} \text { of soil }\end{array}$ & $\begin{array}{c}\text { Decreased root } \\
\text { colonization by the } \\
\text { pathogen }\end{array}$ & $87-100 \%$ \\
\hline $\begin{array}{l}\text { Bacillus amyloliquefaciens } \\
+ \text { bio-organic fertilizer } \\
\text { (BIO23) B. subtilis + bio- } \\
\text { organic fertilizer (BIO36) }\end{array}$ & $\begin{array}{c}\text { Mixed with soil at a density of } 5.5 \times 10^{6} \\
(\mathrm{BIO} 23) \text { and } 7.0 \times 10^{6}(\mathrm{BIO} 36) \mathrm{cfu}^{-1} \text { of } \\
\text { soil }\end{array}$ & Plant growth promotion & $64-65 \%$ \\
\hline
\end{tabular}

** Limitations remained with such inoculation method and rate of application on a large scale infected field.

Shrivastava and Pal (2014) had been evaluated cow dung extract for antibacterial properties against E. coli, Pseudomonas and Staphylococcus aureus. Mannan et al. 2014 reported the of fluids of unpolished rice grain of two traditional aromatic rice genotypes viz. Kalijira and Chinigura were effectively inhibited the Gram negative type Agrobacterium tumefaciens. Jarvis et al. 2001 found that cattle manure could be treated with sodium carbonate to eliminate E. coli and Corral et al. 2006 found sodium bicarbonate (SB) to inhibit the growth of different bacterial pathogen in agar media. Such alternative antibacterial compounds should be tested for effectiveness against $R$. solanacearum which could be considered as alternative options of effective, biologically safe and environment friendly measures of different plant pathogen management.

\section{Propolis}

Propolis (honey bees) consists of about 50 constituents, primarily resins (50\%), waxes (30\%), essential oils (10\%), pollen (5\%) and others (5\%). Propolis is flavonoid-rich product of honey comb, exhibits antibacterial properties (Bosio et al. 2000).

The higher concentration of propolis the greater the inhibition zones against Gram negative type Escherichia coli and Gram positive type Staphylococcus aureus by disc diffusion method (Fig. 2). It is very powerful natural antibiotic (Miorin et al. 2003). The antibacterial activity of propolis may be related to the presence of flavonoids (Bosio et al. 2000). The extent of effectiveness of honey or propolis 
and their chemical composition varies depending on the bee species and geographic region (Miorin et al. 2003).

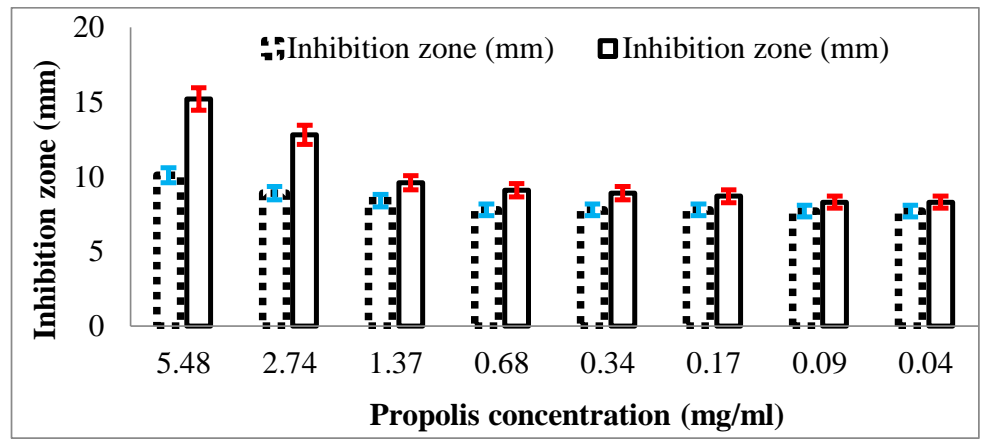

Fig. 2. Inhibition zone of propolis against Gram -ve and Gram +ve by disc diffusion method (Rahman et al. 2010).

\section{Honey}

The antibacterial activity of honey varies very significantly, and depends on the floral source of the honey. The important antibacterial factor in most honeys is hydrogen peroxide, produced in the honey by the action of glucose oxidase which is added to the honey by the bee, but some antibacterial activity is due to substances which are derived from the flowers (Allen et al. 1991).

Balan et al. (2016) found effectiveness of manuka honey against a range of serious bacterial pathogens both from Gram positive and Gram negative type and the higher concentration of honey (from 2.5 to $20 \%$ ) the greater the inhibition was observed. Manuka honey (MH) is produced from the flowers of two New Zealand plants (Fig. 3). The occurrence of high amounts of methylglyoxal (MGO) in New Zealand MH was well documented. MGO was identified as a bioactive compound which is responsible for the antibacterial activity of MH samples (Mavric et al. 2008).

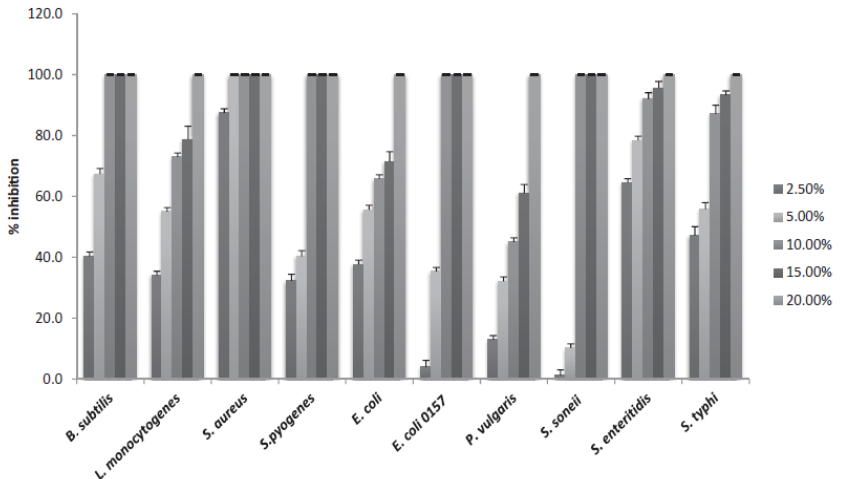

Fig. 3. Antibacterial activity of honey against different bacterial pathogens (after: Balan et al. 2016).

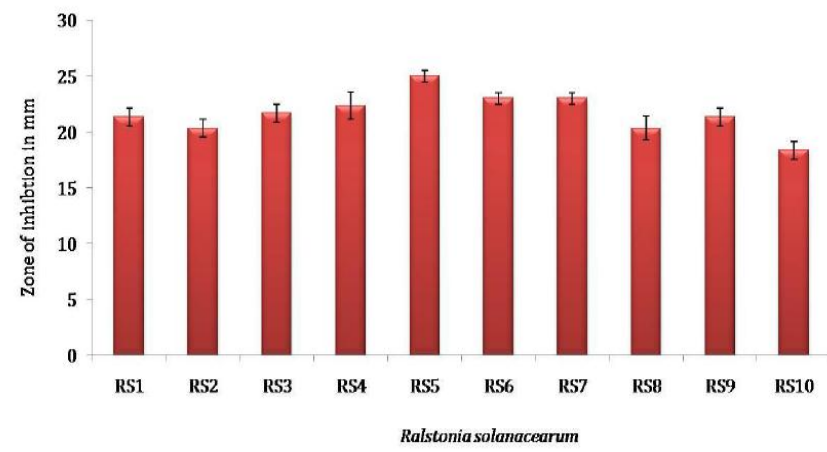

Fig. 4. Inhibition zones of turmeric extracts against ten virulent strains of $R$. solanacearum (after: Narasimha et al. 2015).

\section{Turmeric}

Turmeric is used as a food additive (spice), preservative and coloring agent in Asian countries, including China and South East Asia (Khattak et al. 2005). It is the source of curcumin (diferuloyl methane), a yellow lipid-soluble polyphenolic dietary compound, produced as the rhizome of turmeric. It is widely used in numerous medicinal benefits. Pathological researchers have shown great interest in curcumin (Gupta et al. 2012). A wide range of pharmaceutical attributes of curcumin, such as antioxidative, antimicrobial and wound-healing-protective properties, have been well documented (Aggarwal and Harikumar 2009, Frenkel et al. 2013). 
$10 \%(\mathrm{w} / \mathrm{v})$ turmeric powder extract (Fig. 4) showed an inhibition zone ranged from about 15 to 25 $\mathrm{mm}$ against several virulent strains of $R$. solanacearum (Narasimha et al. 2015). Curcumin was tested for their antimicrobial activities against both Gram positive (Bacillus subtilis NCTC 6276, Staphylococcus aureus NCTC 8530) and Gram negative bacteria (Escherichia coli NCTC 10863, Escherichia coli O157:H7CDC strain G5244, Salmonella typhimurium CDC AMO 3398). Curcumin @ $100 \mathrm{mg} / \mathrm{mL}$ against Gram positive type and @ $250 \mathrm{mg} / \mathrm{mL}$ against Gram negative type was required to inhibit 100\% growth of those strains (Balan et al. 2016) (Fig. 5). However, fat soluble extracts of turmeric and its curcumin component exhibit strong antioxidant activity.

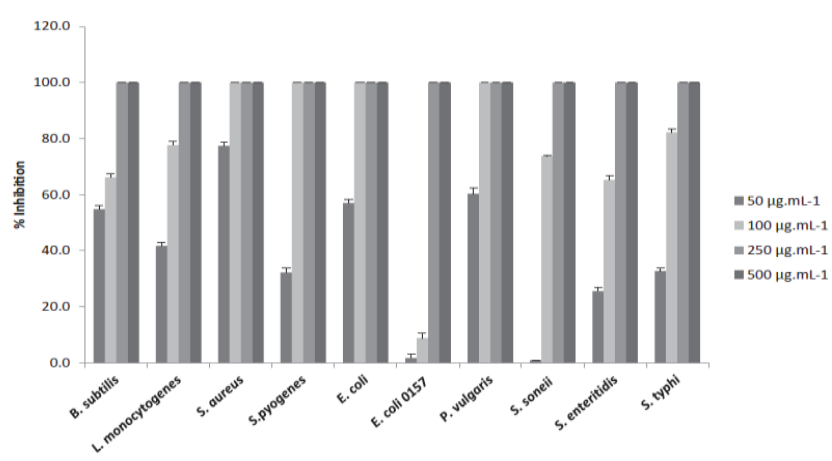

Fig. 5. Inhibition zone of turmeric at different concentrations against different bacterial pathogen (after: Balan et al. 2016).

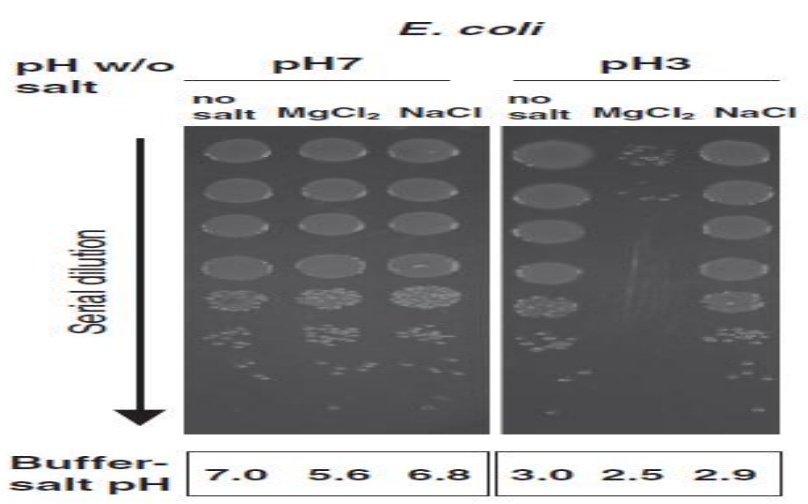

Fig. 6. Antibacterial effect of $\mathrm{MgCl}_{2}$ salt against E. coli (Gram -ve) (after: Oyarzúa et al. 2014).

\section{Magnesium chloride}

Magnesium is an element essential for life and is found ubiquitously in all organisms. It has the properties in a microbiological context with healing and antiseptic characters. The different cations play important roles as enzymatic co-factors, as signaling molecules, and in stabilizing cellular components. Oyarzúa et al. (2014) showed that the magnesium salts in the microbiological experiments typically associated with positive effects (Fig. 6). It focused on the usefulness of magnesium (in form of $\mathrm{MgCl}_{2}$ ) as a stress enhancer against Escherichia coli (K-12).

Table 5. Antimicrobial activity of cow dung extract against different bacterial pathogens (Waziri and Suleiman 2013).

\begin{tabular}{lcccc}
\hline Extract & \multicolumn{5}{c}{ Test microorganisms } \\
\cline { 2 - 5 }$(\mathbf{m g} / \mathbf{m L})$ & B. subtilis IZ & C. bacteria IZ & E. coli IZ & S. aureus IZ \\
\hline 0.20 & -- & -- & -- & -- \\
0.35 & -- & $7.0 \pm 0.32$ & -- & $10 \pm 0.36$ \\
0.70 & -- & $8.0 \pm 0.22$ & -- & $11 \pm 1.54$ \\
2.50 & $0.5 \pm 0.01$ & $8.5 \pm 0.43$ & -- & $13 \pm 2.25$ \\
\hline
\end{tabular}

Values expressed as mean $\pm \mathrm{SD}, \mathrm{n}=6, \mathrm{IZ}=$ Inhibition zone in $\mathrm{mm}$

\section{Cow dung}

Different parts of plants \& oils, animal's wastes have been used by traditional healers in treatment of different categories of diseases with great success. Cow dung and urine has been used as insecticides and has been reported to contain antibiotic agents (Singh 2001, Khanuja 2002). The use of cow dung in the bioremediation of toxicants in the environment (Randhawa and Kullar 2011). It is referred to as chow chips or cow pit in British English while a deposit of the dung is referred to as cow pie in American English (Perry and Morton 2009). Furthermore, a large number of microorganisms which have biological activities and presently in use as antibiotics and antitumor agents have been reported (Carte 1996). 
A study against E. coli, Pseudomonas and Staphylococcus aureus showed that cow dung was highly effective against both of those Gram positive and Gram negative microbes (Shrivastava and Pal 2014). The study revealed that cow dung extract possess antimicrobial properties, which can be used to fight against certain pathogenic diseases and other ailments. Table 5 shows that the cow dung extract has antibacterial activity against Bacillus subtillis, Staphylococcus aureus and was helpful in establishing the antibiotic property of the extract (Waziri and Suleiman 2013).

\section{Aromatic rice}

Use of plant-based compound including vegetables, cereals etc. plays a pivotal role in disease prevention. A great deal of recent research has been focused on the development of new bioactive agents from cereals (Wenzig et al. 2005, Chung et al. 2006, Saikia and Deka 2011). Rice possesses special dietary importance and availability in Asia (WCRF and AICR 1997). Rice-fluid does show an antibiotic effect on Gram negative type Helicobacter pylori and their effect (Ishizone et al. 2007 and Kawakami et al. 2006).

Methanol extract of unpolished grain of two traditional aromatic rice genotypes viz. Kalijira and Chinigura were assayed for their activity on the growth and initiation of crown-gall tumors caused by Gram negative type three Agrobacterium tumefaciens strains (A. tumefaciens- AtS10105, AtTa0112, and AtAc0114) on potato disks (Fig. 6). The results demonstrated a high correlation between the ability of aromatic rice to inhibit the initiation and growth of $A$. tumefaciens strains on potato disks. It was also observed that tumor inhibition was maximum at higher concentrations (1,000 ppm) of Kalizira and Chinigura rice. Fang et al. (2004) suggested that the pure rice phytochemicals were more potent against the pathogenic activity(Duthie et al. 2000, Kong et al. 2003).

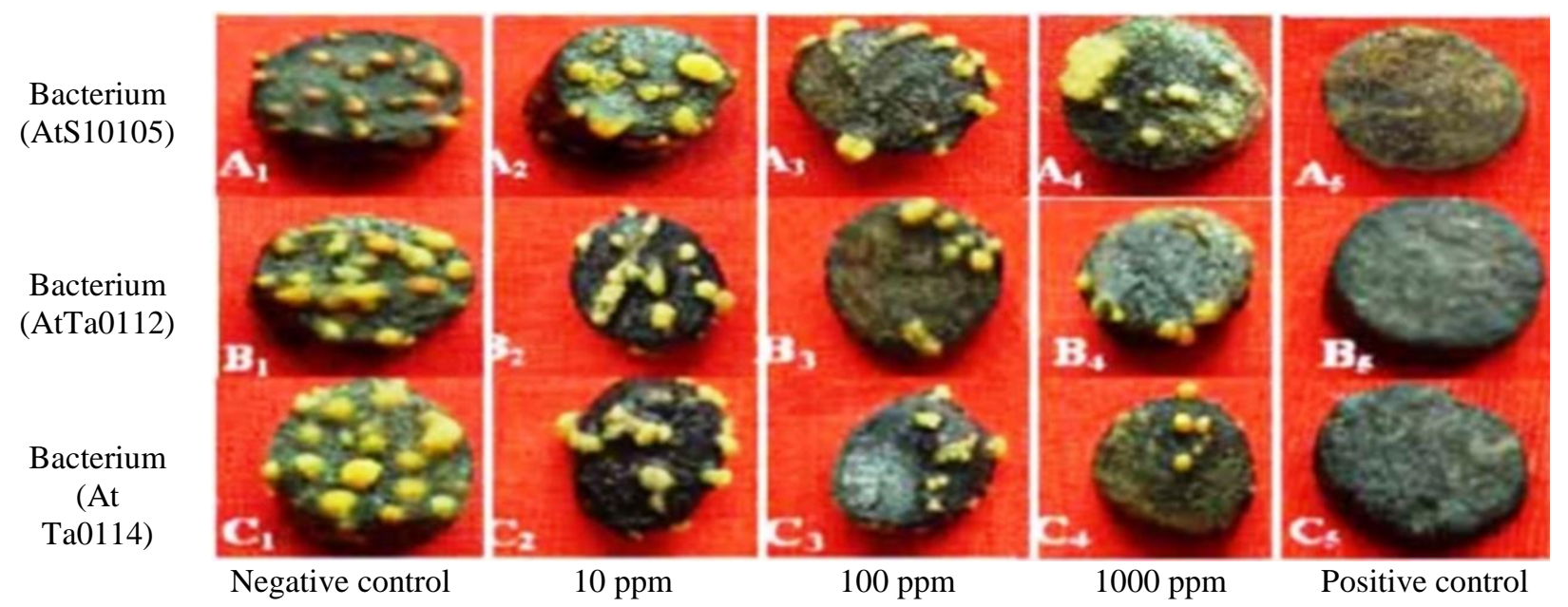

Fig. 6. Tumor inhibition through methanolic extract of Kalijira grain at different concentration caused by Gram negative soil bacteria A. tumefaciens strains (after: Mannan et al. 2014).

Iodine

Estrela et al. (2006) reported that iodoform's action in releasing iodine gives a higher level of reactivity by precipitating proteins and oxidizing essential enzymes (Table 6). Iodine can be dissolved in aqueous potassium iodide, alcohol or make an assembly with a transporter (known as iodofore) and they are classified as disinfectants (Secor and Gudmestad 1993).

In direct exposure test different pastes with and without iodoform (iodine releasing) shows effective inhibition of different bacterial colonies from both Gram positive and Gram negative type except for $B$. subtilis. 
Table 6. Antibacterial effect of different pastes with/ without iodoform (iodine releasing) against different Gram positive and Gram negative type bacteria by direct exposure test (Estrela et al. 2006).

\begin{tabular}{cccccc}
\hline \multicolumn{2}{c}{ Different pastes } & S. aureus AGPC & E. faecalis AGPC & P. aeruginosa AGNR & B. subtillis AGPR \\
\hline \multirow{2}{*}{ CHS } & 24 & --- & --- & --- & +++ \\
& 48 & --- & --- & --- & +++ \\
& 72 & --- & --- & --- & --- \\
\hline \multirow{2}{*}{ CHIS } & 24 & --- & --- & -- & +++ \\
& 48 & --- & --- & --- & --- \\
\hline \multirow{3}{*}{ IS } & 72 & --- & --- & +++ & +++ \\
& 24 & --- & --- & --- & +++ \\
& 78 & --- & --- & --- & +++ \\
\hline
\end{tabular}

$(\mathrm{CHS}=$ Calcium Hydroxide + saline; $\mathrm{CHIS}=$ Calcium Hydroxide + Iodoform + saline; $\mathrm{IS}=$ Iodoform + saline; AGPC = Aerobic Gram-Positive Coccus; AGNR= Aerobic Gram-Negative Rods; AGPR= Aerobic GramPositive Rods, spore forming; $+++=$ presence of growth $\&$--- = absence of growth.)

\section{Sodium bicarbonate}

Sodium bicarbonate, $\mathrm{NaHCO}_{3}$, has particular significance in its ever-growing use for its safety, low cost, low abrasivity, water solubility, acid buffering properties, and, antibacterial properties (McCombs et al. 2001, Barnes 1999). The hypertonic (with greater osmotic pressure) sodium bicarbonate solution causes the more hypotonic microbial cell to lose water, consequently dehydrating and eventually killing the cell (Lawrence and Block 1968). Although these are all desirable outcomes, some studies have shown that the sodium bicarbonate must be allowed to interact at least 30 minutes with the bacteria cell to be fully effective. Fletcher et al. (1984) proved that sodium bicarbonate had no effect on the viability of $S$. mutans when exposed only for a short time. In many cases, sodium bicarbonate was found to be effective against different microorganisms (Fig. 7).

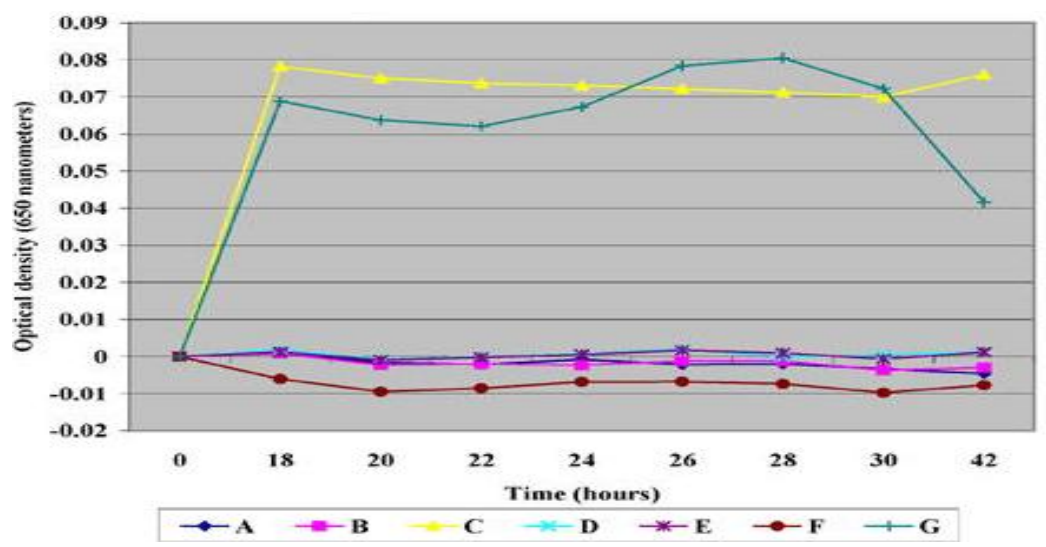

Fig. 7. The effect of sodium bicarbonate and hydrogen per oxide on S. mutans (Kelly and Kristin 2005).

Although sodium bicarbonate has been used mostly to formulate toothpaste and cosmetic products for its antibacterial and acid-neutralizing properties (Kelly and Kristin 2005). It has been reported to be virucidal and inhibited the growth of several fungi (Malik and Goyal 2006, Arslan et al. 2009). Sodium bicarbonate has also been shown to enhance the effectiveness of other agents for controlling mould growth (Wan et al. 2003).

Kelly and Kristin (2005) experimented on the growth of Streptococcus mutans where, row A was filled with distilled water without S. mutans; row B had $10 \%$ sucrose without S. mutans; row C had $10 \%$ sucrose and S. mutans alone; row D had 10\% sucrose, sodium bicarbonate and S. mutans; row E had 
$10 \%$ sucrose, sodium bicarbonate, $3 \%$ hydrogen peroxide and S. mutans; row F had 10\% sucrose, $3 \%$ hydrogen peroxide and $S$. mutans; and row G had $S$. mutans alone (Fig. 7). Rows A (without $S$ mutans), B (without $S$ mutans), C (with $S$ mutans), and G (with $S$ mutans) were used as experimental controls and rows D, E, and F were the experimental groups. Significant statistical differences were observed in Rows D (sodium bicarbonate), E (sodium bicarbonate and hydrogen per oxide), and F (hydrogen per oxide) as compared to row $\mathrm{C}$ ( $S$. mutans in succrose) and $\mathrm{G}$ ( $S$. mutans alone) in the study. However, Rams et al. (1985) shows a five-minute exposure to sodium bicarbonate quickly immobilized the motile rods and they also reports that higher concentrations of sodium bicarbonate may not only suppress harmful bacteria, but also lead to increase in healthy bacteria. Barnes (1999) shows $S$. mutans to be susceptible against 4\% sodium bicarbonate. Additionally, a four-week study by Legier-Vargas et al. (1995) establishes that using a concentration of $65 \%$ sodium bicarbonate lowered the level of $S$. mutans.

As no conventional method was found effective in controlling the pathogen, it is urgent to search and test the effectiveness of environment friendly bioactive compounds to overcome the management limitations against the wilt pathogen.

\section{REFERENCES}

Aggarwal, B. B. and K. B. Harikumar. 2009. Potential therapeutic effects of curcumin, the antiinflammatory agent, against neurodegenerative, cardiovascular, pulmonary, metabolic, autoimmune and neoplastic diseases. Int. J. Biochem. Cell. Biol. 41: 40-59.

Ahmed, N. N., M. R. Islam, M. A. Hossain, M. B. Meah and M. M. Hossain. 2013. Determination of Races and Biovars of Ralstonia solanacearum Causing Bacterial Wilt Disease of Potato. J. Agricul. Sci. 5(6): 86-93.

Ajanga, S. 1993. Status of bacterial wilt in Kenya. In: G. L. Hartman and A. C. Hayward (eds). Bacterial Wilt: Proceedings of an international conference held in Kaohsiung, Taiwan. Australian centre for international agricultural research (ACIAR), Canberra, Australia. 45: 338-340

Akira, M., N. Kazuhiro, S. Masao, T. Hideki and T. Shigehito. 2009. Visualization of Ralstonia Solanacearum cells during biocontrol of bacterial wilt disease in tomato with Pythium oligandrum. General Plant Pathology. 75: 281-287.

Allen, K. L., P. C. Molan and G. M. Reid. 1991. A survey of the antibacterial activity of some New Zealand honeys. J. Pharm. Pharmacol. 43: 817-822.

Arslan U, Ilhan K, Vardar C, Karabulut OA. 2009. Evaluation of antifungal activity of food additives against soilborne phytopathogenic fungi. World J Microbiol Biot. 25(3):537-43.

Balan, P., G. Mal, S. Das and H. Singh. 2016. Synergistic and additive antimicrobial activities of curcumin, manuka honey and whey proteins. J. Food Biochem. 40: 647-654.

Barnes CM. 1999. An evidenced-based review of sodium bicarbonate as a dentifrice agent. Compend. 4(1): 3-11.

Black, L. L., D. L. Wu, J. K. Wang, T. Kalb, D. Abass, J. H. Chen. 2003. Grafting tomatoes for production in hot-wet season: In International cooperators's guide. Asian Vegetable Research and Development Center. The bureau of animal and plant quarantine and health inspection, council of agriculture, China.

Bosio K, C. Avanzini, A. D'Avolio, O. Ozino and D. Savoia. 2000. In vitro activity of propolis against Streptococcus pyogenes. Let. App. Microb. 31: 174-177. 
Buddenhagen, I. W. and A. Kelman. 1964. Biological and physiological aspects of bacterial wilt caused by Pseudomonas solanacearum. Ann. Rev. Phytopathol. 2: 203-230.

Carte, B. K. 1996. Biomedical Potential of Marine Natural Products: Marine organisms are yielding novel molecules for use in basic research and medical applications. Bioscience. 46(4): 271-286.

Champoiseau, P. G., J. B. Jones and C. Allen. 2009. Ralstonia solanacearum race 3 biovar 2 causes tropical losses and temperate anxieties. Plant Health Progress, pp. 1-10.

Chellemi D. O., D. J. Mitchell and A. Barkdol. 1992. Effect of composted organic amendments on the incidence of bacterial wilt of tomato. Proc. Florida State Hort. Soc. 105: 364-366.

Chellemi, D. O., H. A. Dankers, S. M. Olson, N. C. Hodge and J. W. Scott. 1997. Evaluating bacterial wilt-resistant tomato genotypes using a regional approach. Ame. J. Horticul. Sci. 119: 326-329.

Chen, W. Y. 1984. Influence of the root-knot nematode on wilt resistance of flue-cured tobacco infested by Pseudomonas solanacearum. Bull. Tobacco Res. Inst. Taiwan. 21: 44-48.

Chung, I. M., M. Ali, A. Ahmad, J. D. Lim, C.Y. Yu, J. S. Kim. 2006. Chemical constituents of rice (Oryza sativa L.) hulls and their herbicidal activity against duckweed (Lemna paucicostata Hegelm 381). Phytochem. Anal. 17: 36-45.

Ciampi, L. and L. Sequeira. 1980. Influence of temperature on virulence of Race 3 strains of Pseudomonas solanacearum. Am. Potato J. 57: 307-317.

Coelho, N. and F. Nutter. 2005. Bacterial wilt in Amazon State. In: C. Allen, P. Priou and A. C. Hayward (eds.). Bacterial Wilt Disease and the Ralstonia solanacearum Species Complex. APS Press, St. Paul, Minnesota, USA. 332 pp.

Cook, D., E. Barlow and L. Sequeira. 1989. Genetic diversity of Pseudomonas solanacearum: detection of restriction fragment length polymorphisms with DNA probes that specify virulence and the hypersensitive response. Molecular Plant-Microbe Interactions. 2: 113-121.

Cook, D and L. Sequeira. 1994. Strain differentiation of Pseudomonas solanacearum by molecular genetic methods. In: Hayward AC, Hartman GL, eds. Bacterial Wilt, the Disease and its Causative Agent, Pseudomonas solanacearum. Wallingford, UK: CAB International, pp. 77-93.

Corral, L. G., L. S. Post and T. J. Montville. 2006. Antimicrobial effects of sodium bicarbonate. J. Food Sci. 53(3): 981-982.

Cuppels, D. A., R. S. Hanson and A. Kelman. 1978. Isolation and characterization of a bacteriocin produced by Pseudomonas solanacearum. Soc. Gen. Microbiol. 109: 295-303.

Danks C \& Barker I (2000). On-site detection of plant pathogens using lateral flow devices. Bulletin OEPP/EPPO Bulletin. 30: 421-426.

Denny, T. P. 2006. Plant pathogenic Ralstonia species. In: S. S. Gnanamanickam (ed.). Plant-Associated Bacteria. Springer Publishing, Dordrecht, The Netherlands., pp. 573-644

Denny, T. P., S. M. Brumbley, B. F. Carney, S. J. Clough and M. A. Schell. 1994. Phenotype conversion of Pseudomonas solanacearum: its molecular basis and potential function. In: A. C. Hayward, G. L. Hartman (eds.). Bacterial wilt: the disease and its causative agent, Pseudomonas solanacearum. CAB International, Wallingford, UK. 137 pp.

Devi, L. R., M. R. Menon and R. S. Aiyer. 1982. Population threshold of Pseudomonas solanacearum at the onset of first symptoms of wilt in tomato. Indian J. Microbiol. 22: 41-43. 
Dristig, M. C. G. and J. C. Dianese. 1990. Characterization of Pseudomonas solanacearum biovars based on membrane protein patterns. Phytopathology. 80: 641-646.

Duthie, G. G., S. J. Duthie, J. A. M. Kyle. 2000. Plant polyphenols in cancer and heart disease: implications as nutritional antioxidants. Nutr. Res. Rev. 13: 79-106.

Eddins, A. H. 1941. Investigations and control of brown rot of potatoes and related crops caused by Bacterium solanacearum E. F. S. Florida Agricultural and Experimental Station Annual Report. 1941: 117.

Elphinstone, J. G., J. K. Hennessey, J. K. Wilson and D. E. Stead. 1996. Sensitivity of different methods for the detection of Pseudomonas solanacearum in potato tuber extracts. Bulletin OEPP/EPPO Bulletin. 26: 663-678.

Elphinstone J. G., H. M. Stanford and D. E. Stead. 1998. Detection of Ralstonia solanacearum in potato tubers, Solanum dulcamara, and associated irrigation water. In: P. Prior, C. Allen and J. Elphinstone (eds.). Bacterial Wilt Disease: Molecular and Ecological Aspects. Springer Verlag, Berlin (DE)., pp. 133-139.

Elphinstone, J. G. 2005. The current bacterial wilt situation: A global overview. In: C. Allen, P. Prior, and A. C. Hayward (eds.). Bacterial Wilt: The Disease and the Ralstonia solanacearum Species Complex. American Phytopathological Society, St. Paul, MN, pp. 9-28

Enfinger, J. M., S. M. Mccarter and C. A. Jaworski. 1979. Evaluation of chemicals and application methods for the control of bacterial wilt of tomato transplants. Phytopathology. 69: 637-640.

Estrela, C., C. R. A. Estrela, A. C. B. Hollanda, D. A. Decurcio and J. D. Pécora. 2006. Influence of iodoform on antimicrobial potential of calcium hydroxide. J. Appl. Oral Sci. 14(1): 33-7.

Fajinmi, A. A. and Fajinmi, O. B. 2010. An overview of bacterial wilt disease of tomato in Nigeria. $J$. Agric. 5(4): 242-247.

Fang, N., L. Qinglin, J. Zhang, Y. Shanggong, H. Ling, J. M. Ronis, T. M. Badger. 2004. In vitro antitumor activities of methanol extracts from rice protein isolate. Proc. Amer. Assoc. Cancer. Res. 45: 4736.

Farag, N. S., S. M. Lashin, R. S. Abdel-All, H. M. Shatta and A. M. Seif-Elyazal. 1982. Antibiotics and control of potato black leg and brown rot diseases. Agric. Res. Rev. 60(2): 149-166.

Fegan, M., and Prior, P. 2005. How complex is the "Ralstonia solanacearumspecies complex"? In: C. Allen, P. Prior and A. C. Hayward (eds). Bacterial Wilt Disease and the Ralstonia solanacearum Species Complex. American Phytopathological Society, St. Paul, MN . 449-461 pp.

Fletcher, R. D., E. D. Brastins, A. C. Albers and J. Conway. 1984. The effect of the Keyes procedure in vitro on microbial agents associated with periodontal disease. Quintessence Int. 15(3): 329-334.

Floyd, J. 2008. New pest response guidelines: Ralstonia solanacearum race 3 biovar 2. USDA-APHISPPQ-Emergency and Domestic Programs, Riverdale, New york, USA.

Frenkel, M., D. I. Abrams, E. J. Ladas, G. Deng, M. Hardy, J. L. Capodice, M. F. Winegardner, J. K. Gubili, K. S. Yeung, H. Kussmann and K. I. Block. 2013. Integrating dietary supplements in to cancer care. Integr. Cancer Ther. 12(5):369-384.

Froines, J. R. 2010. Findings of the Scientific Review Panel on 'Evaluation of Chloropicrin as a Toxic Air Contaminant' as Adopted at the Panel's February 24, 2010, "Public Meeting." California Department of Pesticide Regulation. 
Gadewar, A. V., T. P. Trivedi and G. S. Sekhawat. 1991. Potato in Karnataka. Tech. Bull. 17: 33

Ghosh, P. P. and N. C. Mandal. 2009. Some disease management practices for bacterial wilt of potato. $J$. Plant Prot. Sci. 1(1): 51-54.

Graham, J., D. A. Jones and A. B. Lloyd. 1979. Survival of Pseudomonas solanacearum race 3 in plant debris and in latently infected potato tubers. Phytopathology. 69: 1100-1103.

Granada, G. A. and L. Sequeira. 1983b. Survival of Pseudomonas solanacearum at low temperatures. Fitopatologia. 18: 22-24.

Grimault, V., G. Anais and P. Prior. 1994. Distribution of Pseudomonas solanacearum in the stem tissues of tomato plant with different levels of resistance to bacterial wilt. Plant Pathol. 43: 663668.

Guidot, A., P. Prior, J. Schoenfeld, S. Carrere, S. Genin, and C. Boucher. 2007. Genomic structure and phylogeny of the plant pathogen Ralstonia solanacearum inferred from gene distribution analysis. J. Bacteriology. 189: 377-87.

Gupta, S. C., S. Patchva, W. Koh and B. B. Aggarwal. 2012. Discovery of curcumin, a component of golden spice, and its miraculous biological activities. Clin. Exp. Pharmacol. Physiol. 39: 283-299.

Hartman, G. L. and J. G. Elphinstone. 1994. Advances in the control of Pseudomonas solanacearum race 1 in major food crops. In: A. C. Hayward and G. L. Hartman (eds.). Bacterial wilt: The disease and its causal agent, Pseudomonas solanacearum. CAB International, Wallingford, UK, pp. 157-177.

Hayward, A. C. 1994. The hosts of Pseudomonas solanacearum. In: A. C. Hayward and G. L. Hartman. (eds.) Bacterial wilt: The Disease and its Causative Agent, Pseudomonas solanacearum. CAB International, Wallingford, UK, pp. 9-24.

Hayward, A. C. 1964. Characteristics of Pseudomonas solanacearum. J. Appl. Bacteriol. 27: 265-277.

Hayward, A. C. 1991. Biology and epidemiology of bacterial wilt caused by Pseudomonas solanacearum. Annual Rev. Phytopathol. 29: 65-87.

Hayward, A. C. 1994b. The hosts of Pseudomonas solanacearum. In: A. C. Hayward, G. L. Hartman (eds.). Bacterial wilt: The Disease and its Causative Agent, Pseudomonas solanacearum. CAB International, Wallingford, UK, pp. 9-24.

He, L.Y. 1983. Characteristics of strains of Pseudomonas solanacearum from China. Plant Disease. 67: 1357-1361.

Hoffler. H. and B. O. Ochieng. 2008. High Commodity Prices-Who gets the Money? Preliminary findings for World Food Day. Heirich Boll Foundation.

Horton, W. H. 1987. Compendium of potato diseases. American Phytopathological Society, St. Paul, Minnesota, USA, pp. 29-31.

Ishizone, S., F. Maruta, K. Suzuki, S. Miyagawa, M. Takeuchi, K. Kanaya, K. Oana, M. Hayama, Y. Kawakami and H. Ota. 2007. In vivo bactericidal activities of Japanese rice-fluid against H. pylori in a Mongolian gerbil model. Int. J. Med. Sci. 4: 203-208.

Jarvis, G. N., M. W. Fields, D. A. Adamovich, C. E. Arthurs and J. B. Russell. 2001. The mechanism of carbonate killing of Escherichia coli. Appl. Microbiol. 33: 196-200. 
Johnson, G. and L. A. Schaal. 1952. Relation of chlorogenic acid to scab resistance in potato. Science. 115: $627-629$.

Kabeil, S. S., S. M. Lashin, M. H. El-Masry, M. A. El-Saadani, M. M. Abd-Elgawad and A. M. AboulEinean. 2008. Potato Brown Rot Disease in Egypt: Current Status and Prospects. Ame. Eu. J. Agric. Environ. Sci. 4(1): 44-54.

Kawakami, Y., K, Oana, M. Hayama, H, Ota, M. Takeuchi, K. Miyashita, T. Matsuzawa and K. Kanaya. 2006. In vitro bactericidal activities of Japanese rice-fluid against Helicobacter pylori strains. Int. J. Med. Sci. 3: 112-116.

Kelly, J. S. and Kristin, R. T. 2005. Sodium Bicarbonate and Hydrogen Peroxide: The Effect on the Growth of Streptococcus mutans. J. Dent. Hyg. 79(4): 7.

Kelman, A. 1953. The bacterial wilt caused by Pseudomonas solanacearum. Tech. Bull. North Carolina Agric. Exp. Stat. 99: 1-103.

Kelman, A. 1954. The relationship of pathogenicity in Pseudomonas solanacearum to colony appearance on a tetrazolium medium. Phytopathology. 44: 693-695.

Kelman, A. 1998. One hundred and one years of research on bacterial wilt. In: P. H. Prior, C. Allen and J. Elphinstone (eds.). Bacterial wilt disease: Molecular and ecological aspects. Reports of the second international bacterial wilt symposium. Gosier, Guadeloupe, France, pp. 1-5.

Kelman, A. and L. H. Person. 1961. Strains of Pseudomonas solanacearum differing in pathogenicity to tobacco and peanut. Phytopathology. 51: 158-161.

Kelman, A. and L. Sequeira. 1965. Root-to-root spread of Pseudomonas solanacearum. Phytopathology. 55: 304-309.

Kennedy, J. and J. Bek. 1998. Selection and Use of Disinfectants. Nebraska Cooperative Extension.

Khanuja, S. P. S. 2002. Pharmaceutical composition containing cow urine distillate and an Antibiotic. US patent 6410059 .

Khattak, S., S. Rehman, V. Shan, W. Ahmad and M. Ahmad. 2005. Biological effects of indigenous medicinal plants Cucurma longa and Alpinia galangal. PubMed. 76(2): 254-257.

Kong, J. M., L. S. Chia, N. K. Goh, T. F. Chia and R. Brouuillar. 2003. Analysis and biological activities of anthocyanins. Phytochemistry. 64: 923-933.

Lawrence, C. A. and S. S. Block. 1968. Disinfection, sterilization, and preservation. Philadelphia (PA), Lea and Febiger. 641 pp.

Legier-Vargas, K, S. A. Mundorff-Shrestha, J. D. Featherstone and L. M. Gwinner. 1995. Effects of sodium bicarbonate dentifrices on the levels of cariogenic bacteria in human saliva. Caries Res. 29(2): 143-7.

Leksomboon, C., N. Thaveechai, W. Kositratana and Y. Paisooksantivatana. 2000. Antiphytobacterial activity of medicinal plant extracts. Science. 54: 91-97.

Malik, Y. S. and S.M. Goyal. 2006. Virucidal efficacy of sodium bicarbonate on a food contact surface against feline calicivirus, a norovirus surrogate. Int J Food Microbiol. 109(1-2):160-163.

Mannan, M. A., T. C. Sarker, A. H. Kabir, M. M. Rahman and M. F. Alam. 2014. Antitumor properties of two traditional aromatic rice genotypes (Kalijira and Chinigura). Avicenna J. Phytomed. 4(1): $31-42$. 
Mavric, E., S. Wittmann, G. Barth and T. Henle. 2008. Identification and quantification of methylglyoxal as the dominant antibacterial constituent of manuka (Leptospermum scoparium) honeys from New Zealand. Mol. Nutr. Food Res. 52: 483-489.

Mbaka, J. N., J. K. Gitonga, C. W. Gathambari, B. G. Mwangi, P. Githuka and M. Mwangi. 2013. Identification of knowledge and technology gaps in high tunnels tomato production in Kirinyaga and Embu counties.

McCombs, G., M. Green and J. Root. 2001. Effects of a chewable sodium bicarbonate oral composition on plaque and gingivitis. J. Contemp Dent. Pract. 2(1): 31-34.

Miorin, P. L., N. C. J. Levy, A. R. Custodio, W. A. Bretz and M. C. Marcucci. 2003. Antibacterial activity of honey and propolis from Apis mellifera and Tetragonisca angustula against Staphylococcus aureus. J. Appl. Microb. 95: 913-920.

Mukherjee, N. and M. K. Dasgupta. 1989. Udvider Rog (Plant Disease). Poschimbongo Rajyo Pustak Porsad (West Bengal State Book Board) Kolkata, India.

Nagabhushan, M. and S. V. Bhide. 1992. Curcumin as an inhibitor of cancer. Am. Coll. Nutr. 11: 192198.

Narasimha, M. K., K. Soumya and C. Srinivas. 2015. Antibacterial Activity of Curcuma longa (Turmeric) Plant Extracts Against Bacterial Wilt of Tomato Caused by Ralstonia solanacearum. Int. J. Sci. Res. 4(1): 2136-2141.

Nesmith, W. C. and S. F. Jenkins. 1985. Influence of antagonists and controlled matrix potential on the survival of Pseudomonas solanacearum in four North Carolina soils. Phytopathology. 75: 11821187.

Okabe, N. and M. Goto. 1963. Bacteriophages of plant pathogens. Ann. Rev. Phytopathol. 1: 397-418.

Oyarzúa Alarcón, P., K. Sossa, D. Contreras, H. Urrutia and A. Nocker. 2014. Antimicrobial properties of magnesium chloride at low $\mathrm{pH}$ in the presence of anionic bases. Magnes Res. 27(2): 57-68

Perry J. B. and D. Morton. 2009. Manual of Clinical Microbiology. 7th ed. American Society for Microbiology, Washington DC, pp. 302-305.

Poussier, S., P. Thoquet and D. Trigalet-Demery. 2003. Host plant-dependent phenotypic reversion of Ralstonia solanacearum from non-pathogenic to pathogenic forms via alterations in the pheA gene. Mol. Microbiol. 49: 991-1003.

Prior, P. H., C. Allen and J. Elphinstone. 1998. Bacterial Wilt. In: P. H. Prior, C. Allen and J. Elphinstone (eds.). Bacterial wilt disease: Molecular and ecological aspects: Reports of the second international bacterial wilt symposium, Gosier, Guadeloupe, France.

Rahman, M. M., A. Richardson and M. S. Azirun. 2010. Antibacterial activity of propolis and honey against Staphylococcus aureus and Escherichia coli. Afr. J. Microbiol. Res. 4(16): 1872-1878.

Rams TE, Keyes PH, Wright WE, Howard SA. 1985. Long-term effects of microbiologically modulated periodontal therapy on advanced adult periodontitis. J. Am. Dent. Assoc. 111(3): 429-41.

Randhawa, G. K. and J. S. Kullar. 2011. ISRN Pharmacology. 7 pp.

Saddler, G. S. 2005. Management of bacterial wilt disease. In: C. Allen, P. Prior and A. C. Hayward (eds). Bacterial Wilt Disease and the Ralstonia solanacearum Species Complex. American Phytopathological Society, St., pp. 121-132. 
Saikia, D. and S. C. Deka. 2011. Staple food to neutraceuticals. Int. J. Food. 18: 21-30.

Schaad, N. W., A. Takatsu and J. C. Dianese. 1978. Serological identification of strains of Pseudomonas solanacearum in Brazil. Proceedings of Fourth International Conference on Plant Pathogenic Bacteria. Angers, France, pp. 295-300.

Secor, G. A. and N. C. Gudmestad. 1993. Handling and planting seed tubers. In: R. C. Rowe (ed.). Potato Health Management. pp. 27-30.

Seneviratne, S. N. 1988. Soil survival of Pseudomonas solanacearum. Bacterial Diseases of the Potato: Report of the Planning Conference on Bacterial Diseases of the Potato. CIP, Lima, Peru, pp. 8592.

Shekhawat, G. S. and M. C. M. Perombelom. 1991. Factors affecting survival in soil and virulence of Pseudomonas solanacearum. J. Plant Dis. Prot. 93: 258-267.

Shekhawat, G. S., S. K. Chakrabarti and A. V. Gadewar. 1992. Potato bacterial wilt in India. Indian Council of Agricultural Research, India. Tech. Bull. 38: 16-39.

Shrivastava S. and A. M. A. Pal. 2014. Cow dung- a boon for antimicrobial activity. Life Sciences Leaflets. 55: 3.

Singh. S. 2001. Cow urine has anti-leishmania donovani effect in vitro. Int. J. Cow Sci. 1(2): 72-73.

Sitaramaiah, K. and S. K. Sinha. 1984. Interaction between Meloidogyne javanica and Pseudomonas solanacearum on brinjal. Indian J. Nematol. 14: 1-5.

Smith, E. F. 1896. A bacterial disease of the tomato, eggplant and Irish Potato Bacillus solanacearum. U.S. Dept. Agr. Div. Veg. Phys. Path. Bull. 12: 1-28.

Tung, P. X., E. T. J. R. Rasco, P. Vander Zaag and P. Schmiediche. 1990. Resistance to Pseudomonas solanacearum in the potato: II Aspects of host-pathogen-environment interaction. Euphytica. 45: 211-215.

USDA. 2003. Biological control of Fusarium wilt and other soilborne pathogenic fungi. http://www.ars.usda.gov/research/projects/projects.

Van Elsas, J. D., P. Kastelein, P. M. de Vries and L. S. van Overbeek. 2001. Effects of ecological factors on the survival and physiology of Ralstonia solanacearum bv. 2 in irrigation water. Can. J. Microbiol. 47: 842-854.

Velikova, M., V. Bankova, I. Tsvetkova, A. Kujumgiev and M. C. Marcucci. 2000a. Antibacterial entkaurene from Brazilian propolis of nativestingless bees. Fitoterapia. 71: 693-696.

Velikova, M., V. Bankova, M. C. Marcucci, I. Tsvetkova and A. Kujumgiev. 2000b. Chemical composition and biological activity of propolis from Brazilian meliponinae. Zeistsch. Naturfors. 55(C): 785-789.

Wan, Y. K, S. P. Tian and G. Z. Qin. 2003.Enhancement of biocontrol activity of yeasts by adding sodium bicarbonate or ammonium molybdate to control postharvest disease of jujube fruits. Lett Appl Microbiol. 37(3): 249-53.

Waziri, M. and J. S. Suleiman. 2013. Analysis of some element and antimicrobial activity of evaporated extract of cow dung against some pathogens. J. Sci. Res. 5(1): 135-141. 
Weller, S. A., Elphinstone, J. G., Smith, N. C., Boonham, N., and Stead, D. 2000. Detection of Ralstonia solanacearum strains with a quantitative, multiplex, realtime fluorogenic PCR (TaqMan) assay. Appl. Environ. Microbiol. 66: 2853-2858.

WCRF and AICR. 1997. Patterns of Diet and Cancer. In: World Cancer Research Fund and American Institute for Cancer Research (eds.). Food, Nutrition and the Prevention of Cancer: a Global Perspective, pp. 20-52.

Wenzig, E., O. Kunert, D. Ferreira, M. Schmid, W. Schuhly and R. Bauer. 2005. Flavonolignans from Avena sativa. J. Nat. Prod. 68: 289-292.

Yuliar, Y. A. Nion and K. Toyota. 2015. Recent Trends in Control Methods for Bacterial Wilt Diseases Caused by Ralstonia solanacearum. Microbes Environ. 30(1): 1-11.

Zhang, Y. X., J. Y. Hua and L. Y. He. 1993. Effect of infected groundnut seeds on transmission of Pseudomonas solanacearum. Bacterial Wilt Newsletter. 9: 9-10.

Zumla, A. and A. Lulat. 1989. Honey - a remedy rediscovered. J. R. Soc. Med. 82: 384-385.

DOI: $\underline{\text { http://dx.doi.org/10.3329/jbcbm.v4i1.37879 }}$ 